\title{
ATTITUDES TOWARDS ECONOMIC RISK AND THE GENDER PAY GAP*
}

\author{
Anh T. Le and Paul W. Miller \\ School of Economics and Finance Curtin University \\ Wendy S. Slutske and \\ University of Missouri \\ Nicholas G. Martin \\ Queensland Institute of Medical Research
}

\section{Keywords}

Wages; Gender; Risk; Wage Gap

\section{INTRODUCTION}

A great part of research in labor economics has aimed to understand aspects of earnings inequality. These studies have addressed differences across birthplace groups, differences according to race, and differences between males and females, as well as difference between more narrowly defined groups, such as according to sexual orientation and handedness. Among these topics, it is the analysis of gender differences which has generated the greatest interest.

Studies of gender differences in earnings have typically been based on a Blinder (1973)/ Oaxaca (1973) type decomposition. The studies differ in their emphasis; with the roles of intermittent labor market experience (Polachek, 1975), self selection (Miller, 1987a), and the wage structure (Blau and Kahn, 1997) being among the many issues examined. Invariably, regardless of the statistical approach, specification of the estimating equation, data set used or time period covered, women are shown to earn less than men, ceteris paribus. This finding emerges even in countries such as Australia, which has a history of comparable worth principles underpinning institutionalized wage setting.

The origins of this standardized female wage differential appear elusive. In the current paper we examine the extent to which it may be linked to gender differences in attitudes towards economic risk (see Schubert, Brown, Gysler and Brachinger (1999), Powell and Ansic (1997) and Eckel and Grossman (2002) for studies of gender differences in risk aversion).

\footnotetext{
* This work was supported by National Institutes of Health Grant MH66206 (to Wendy Slutske). Miller acknowledges financial assistance from the Australian Research Council. We are grateful to an anonymous referee for helpful comments.

(C) 2010 Elsevier B.V. All rights reserved.

For correspondence: Professor Paul W. Miller School of Economics and Finance Curtin Business School Curtin University GPO Box U1987 Perth WA 6845 Phone: +61 892667758 Fax: +61 892663026 Paul.Miller@curtin.edu.au.

Publisher's Disclaimer: This is a PDF file of an unedited manuscript that has been accepted for publication. As a service to our customers we are providing this early version of the manuscript. The manuscript will undergo copyediting, typesetting, and review of the resulting proof before it is published in its final citable form. Please note that during the production process errors may be discovered which could affect the content, and all legal disclaimers that apply to the journal pertain.
} 
Attitudes towards economic risk are used to reflect differences in individual decisionmaking processes that might help account for the variation in earnings across individuals.

A behavioral genetics approach is first taken, based on Le, Miller, Slutske and Martin (2010), to review findings on gender differences in attitudes towards economic risk. The risk variable is then related to earnings using estimating equations based on both human capital and behavioral genetics models. The results suggest that more positive attitudes towards economic risk-taking are associated with higher earnings, but the partial effect of risk attitudes on earnings would have to be over eight times greater than that estimated to fully account for the standardized gender pay gap.

The structure of the paper is as follows. Section II outlines the behavioral genetics model used. Section III describes the data set. The results of the statistical analyses are presented in Section IV, while concluding comments are given in Section V.

\section{METHODOLOGY}

The findings reported below are based on both behavioral genetics and human capital models. The human capital model of earnings determination is well known to economists, and is not outlined here. Economists will generally not be familiar with the behavioral genetics model employed below in the study of both variations in attitudes towards risk and earnings determination, and so a brief outline is provided. This model uses data on both identical and non-identical twins to assign the variation in a variable, such as economic risk taking or earnings, to either additive genetic effects (A), shared environmental effects (C), or unshared environmental effects (E). This decomposition enables the quantification of heritability $\left(h^{2}\right)$ as $h^{2}=A /(A+C+E)$ and common environmentality $\left(c^{2}\right)$ as $c^{2}=C /(A+C+$ $E) .{ }^{1}$ Unshared environmental effects $\left(e^{2}\right)$ are thus given as $e^{2}=1-h^{2}-c^{2}$. There are various statistical methodologies that can be used to implement this decomposition, and the one used here is the multiple regression framework proposed by DeFries and Fulker (1985). We use this model because it also facilitates a more detailed study of the determinants of earnings than that permitted by the conventional human capital model.

The model of DeFries and Fulker (1985) is based on the following estimating equation:

$$
Y_{i j}=\alpha_{0}+\alpha_{1} Y_{-i j}+\alpha_{2} R_{i j}+\alpha_{3} Y_{-i j} R_{i j}+\alpha_{4} X_{i j}+\varepsilon_{i j}, j=1, \ldots, n
$$

where $Y_{i j}$ is the outcome measure (economic risk taking, earnings) for individual $i$ in twin pair $j, Y_{-i j}$ is the outcome measure of the individual's co-twin, $R_{i j}$ is a coefficient of genetic relationship, which is defined using the fractions of gene frequencies derived in simple biometrical models, namely 1 for identical twins and 0.5 for non-identical twins, $Y_{-i j} R_{i j}$ is an interaction term between the $Y_{-i j}$ and $R_{i j}$ variables that is the crucial part of the estimating equation which enables heritability to be assessed, $X_{i j}$ is a set of other variables (e.g., gender, age, educational attainment) that are held to influence the outcome analysed, and $\varepsilon_{i j}$ is a stochastic disturbance term.

Given the definition of $R_{i j}, \alpha_{3}$ will be twice the difference between the identical (MZ) and non-identical (DZ) twins in the regression coefficients on the outcome $(Y)$ measure for the co-twin. In other words, $\alpha_{3}=2\left(\alpha_{M Z}-\alpha_{D Z}\right)$, which given the model formulation can also be expressed as $\alpha_{3}=2\left(r_{M Z}-r_{D Z}\right)$, where $r$ is the correlation coefficient. Thus, $\alpha_{3}$, under the

\footnotetext{
${ }^{1}$ The estimation of heritability by comparing resemblances between twins relies on the fact that identical (monozygotic or MZ) twins are twice as genetically similar as non-identical (dizygotic or DZ) twins, and so heritability is approximately twice the difference in correlation between MZ and DZ twins, $h^{2}=2\left(\mathrm{r}_{\mathrm{MZ}}-\mathrm{rDZ}\right)$. In these studies, $c^{2}=\mathrm{rDZ}-0.5 h^{2}$, and $e^{2}=1-\mathrm{r} \mathrm{MZ}$.
} 
standard assumptions of an additive model, random mating, and non-common environment of a DZ twin is not correlated with his/her co-twin's genes, provides a direct estimate of heritability $\left(h^{2}\right)$ of the outcome measure being analysed (see footnote 1$) \cdot 2$

$\alpha_{1}$ in equation (1) is an estimate of the twin resemblance that is independent of the genetic resemblance captured in the model terms in $R_{i j}$. $\alpha_{1}$ is therefore an estimate of common environmental influence, $c^{2} .^{3}$

This model has been extended to address differential heritability (by cognitive ability, age, gender) by a number of authors. Differential heritability by gender (DeFries, Gillis and Wadsworth, 1993) can be addressed through the inclusion of a set of interaction terms between gender $\left(F_{i j}\right)$ and the three behavioral genetics terms $\left(Y_{-i j}, R_{i j}, Y_{-i j} R_{i j}\right)$ in the basic DeFries and Fulker (1985) model. Thus, the extended model of DeFries and Fulker (1985), with the focus on gender, is:

$$
Y_{i j}=\beta_{0}+\beta_{1} Y_{-i j}+\beta_{2} R_{i j}+\beta_{3} Y_{-i j} R_{i j}+\beta_{4} F_{i j}+\beta_{5} F_{i j} Y_{-i j}+\beta_{6} F_{i j} R_{i j}+\beta_{7} F_{i j} Y_{-i j} R_{i j}+\beta_{8} X_{i j}+\varepsilon_{i j}
$$

In this model, where $F_{i j}$ is a dichotomous variable, defined to equal one for females and zero for males, $\beta_{3}$ is the estimate of heritability for males and $\beta_{7}$ is the estimate of the differential effect of $h^{2}$ for females compared to males. Similarly, $\beta_{1}$ is the estimate of common environmental influence for males, and $\beta_{5}$ is the estimate of the differential effect of $c^{2}$ for females compared to males.

Each of these models can be extended by the inclusion of the covariates typically considered in standard analyses of the outcome under consideration. Variables for age, gender and educational attainment are included in the equations presented below. This extension of the model changes the interpretation of the estimates for the common environment and heritability variables. Specifically, where the personal characteristics added to the model are correlated with the genetic endowments that are identified by the co-twin's outcome variable, the genetic effects identified by the model will be distorted (see Miller, Mulvey and Martin, 2001). For example, if there is a positive association between parents' genetic endowments and the added regressors, the effects of the co-twin's genotype will tend to be minimized in the model, providing a conservative estimate of the genetic effect on economic risk taking or income in the analysis. For this reason, results from both the basic and extended models of DeFries and Fulker (1985) will be presented.

All estimations presented below are based on the double-entry data method of Cherny, DeFries and Fulker (1992). This method accommodates the fact that there is no single way of categorizing members of a twin pair as "twin" and "co-twin" by entering the data for each member of a twin pair in the estimating equation twice - once as twin $\left(Y_{i j}\right)$ and once as cotwin (i.e., $\left.Y_{-i j}\right)$.

Note that the regression models outlined above do not constrain the estimates of $h^{2}$ and $c^{2}$ to be in the unit interval. In many applications it is possible to find negative estimates of $c^{2}{ }^{4}$ Cherny, DeFries and Fulker (1992) have shown, however, that if the estimate of $c^{2}$ is not significant, the corresponding model term can be omitted from the estimating equation and

\footnotetext{
${ }^{2}$ See Miller, Mulvey and Martin (2001) for a discussion of these and other assumptions in the variance components models. ${ }^{3}$ See Le, Miller, Slutske and Martin (2010) for discussion of the statistical properties of these estimators, and of the power of the multiple regression model compared to maximum likelihood estimation of the genetic and common environmental parameters from the covariance structure of the data.

${ }^{4}$ This can indicate the presence of genetic non-additivity, including genetic dominance (allelic interaction) or epitasis (gene*gene interaction).
} 
the estimate of $h^{2}$ obtained from this modified model will be unbiased. This practice is followed below when negative values of $c^{2}$ are obtained.

Among the assumptions underlying this behavioral genetics model, the one that is often contested is the absence of assortative mating. Assortative mating will increase the genetic variance between families, so that what is estimated as shared environment is confounded with extra additive genetic variance. Martin (1978) provides a post-estimation adjustment for assortative mating, based on the marital correlation for the particular dependent variable (risk or earnings) being analysed. ${ }^{5}$ This enables a component of the estimate of shared environment to be assigned to heritability. However, in the estimations below, the shared environment component of the variance in either attitudes to risk or earnings is estimated as zero, and so Martin's (1978) adjustment is not required.

\section{DATA}

The data used in this study are from the Australian Twin Study of Gambling, and are described in Slutske et al. (2009) and Le et al. (2010). The data were collected over 2004-2007 from members of the Australian Twin Registry Younger Twin Cohort. This comprises a volunteer panel of twins born between 1964 and 1971. The sample size for the Study of Gambling is 4,764, covering 3,750 twins from complete twin pairs and 1,014 from incomplete pairs. Of the complete pairs, 867 are identical twins and 1,008 are non-identical twins.

The two key variables used in the analysis are earnings and attitudes towards risk. The earnings data were collected in categorical form, and we follow Miller, Mulvey and Martin (2006) by converting these to a continuous measure, using the mid-points of closed categories, and a value of 1.5 times the lower threshold for the open-ended upper category. Only individuals with positive earnings are included in the main set of analyses. Earnings data collected in a year other than 2004 have been indexed to 2004 values using the consumer price indx. The attitudes to economic or financial risk data are obtained from responses to the question: "On a scale from 1 to 10, with 1 meaning no risk, and 10 meaning extremely high risk, how much risk are you willing to tolerate when deciding how to invest your money?".

Le et al. (2010) demonstrate that the RISK variable has the expected relationship with selfreports of decision-making under uncertainty in the survey, such as the preferred way to allocate funds (banks versus investment) and gambling propensities. The question the RISK variable is derived from is similar to the measure in Dohmen et al. (2005). Dohmen et al. (2005) show, on the basis of analysis of a data set that contained both information collected via general risk attitude questions and information from a standard lottery experiment, that these types of survey measures are behaviorally relevant.

The main set of analyses that follow are based on the 2,288 members of complete twin pairs (i.e., 1,144 pairs of twins) where each member was employed on either a full-time or parttime basis, had positive earnings, and valid data on each of these three explanatory variables and on the covariates included in the estimating equations. Of these twin pairs, 592 are identical twins, and 552 are non-identical twins.

\footnotetext{
$5^{5}$ For example, in a study of the heritability of educational attainment (Miller et al., 2001), the marital correlation in education levels was 0.426, and three-quarters of the shared environment component of the variance in educational attainments was therefore held to be more appropriately viewed as a part of the heritability component. See also Baker, Treloar, Reynolds, Heath and Martin (1996) for an application of this post-estimation adjustment.
} 
The covariates included in the analysis are female, age, educational attainment, and a parttime employment variable (earnings determination only). Variable definitions, along with means, are provided in Appendix A. Of note is that educational attainment refers to the years of primary and secondary schooling for workers without post-school qualifications, and an assumed "years of full-time schooling" equivalent of their qualification for workers who possess post-school qualifications (e.g., university degrees, technical college).

Appendix A also provides means of several variables for the full sample (4375 observations with valid data on variables other than the labor market outcomes). This provides one handle on the potential importance of sample selection bias. It is observed that the mean age of the purged sample (37.70 years for the pooled sample of males and females) is similar to that of the full sample (37.67 years). The workers in the purged sample are more educated than the full sample (by 0.3 of a year overall), and have slightly more favorable disposition towards taking economic risk (males only). Thus these comparisons draw attention to some, though reasonably minor, differences, between the two sets of data. A second handle on the potential importance of sample selection bias can be obtained by examining models estimated on the full and purged data sets. Le et al. (2010) present analyses of the determinants of economic risk taking using the full sample. They report an estimated of the heritability of attitudes towards economic risk taking of 0.221 in the basic model of DeFries and Fulker (1985), which is the same as the estimate reported below. ${ }^{6}$ The partial effect of education on economic risk taking was 0.097 in Le et al. (2010). It is 0.102 in the analyses below. These comparisons suggest that the sample selections adopted do not impact the analyses of the determinants of attitudes towards economic risk. The importance of selection bias to the study of earnings could be examined using a Heckman (1979) selection correction. This is not pursued here owing to reservations over the robustness of the correction (see Puhani, 2000; Miller, 1987b).

\section{STATISTICAL ANALYSES}

\section{(c) Economic Risk}

Economic risk is a characteristic that is often argued to be a determinant of many of the labor market choices that individuals make (e.g., human capital investment, occupational choice). Much of the literature that has assessed determinants of variations in propensities to take economic risk has shown that females are more risk averse than males (see, for example, Dohmen et al., 2005). Le et al. (2010) provide analyses of the extent to which attitudes towards economic risk are heritable and on whether this heritability differs between men and women. Their research was based on a combined sample of labor market participants and non-participants in the paid labor force. The analyses that follow are based only on those in paid employment. As discussed above, estimation of the model on this select sample and comparison with the findings of Le et al. (2010) permits assessment of whether the results are affected by selection of the sample.

Table 1 provides information on the distribution of the sample across the categories in the economic risk taking variable. These data show that the distribution of the responses to the RISK question for females is skewed towards the lower response categories compared to that for males. In particular, females are over-represented in the first four categories and underrepresented in categories 5-8. The mean of the risk variable for females is 4.13 , and this is significantly different from the mean of 4.89 for males.

In the first instance a simple linear regression model is estimated that relates the measure of attitudes towards economic risk to variables for female, age and educational attainment. This

\footnotetext{
${ }^{6}$ See Martin and Wilson (1982) for analysis of the biases that can arise in studies of heritability when using truncated samples.
} 
estimation treats the sample as one of individuals rather than a sample of twins. The results from this estimation are presented in column (i) of Table 2. Each of the variables in the column (i) specification is statistically significant.

The results in column (i) of Table 2 show that, consistent with the literature, females have less positive attitudes towards economic risk than their male counterparts. The coefficient on the female variable is -0.819 . Recall that economic risk is measured on a 10-point scale, and the mean of the measure is 4.538 and the standard deviation $2.049 .{ }^{7}$ Hence, the change in attitudes towards economic risk associated with being female is around two-fifths of a standard deviation of the dependent variable.

Attitudes towards economic risk are more favorable among the better educated, ${ }^{8}$ and this finding is also consistent with the literature. Comparison of the coefficients on the female and educational attainment variables shows that the effect associated with being female is the equivalent of 7.3 years of education, which is almost equal to the range of the educational attainment variable in these data (which is nine years). This emphasises the extent of the differences in attitudes towards economic risk between females and males.

Attitudes towards economic risk are also more favorable among older than younger persons. This relationship is contrary to the literature (see, for example, Dohmen et al., 2005, where willingness to take risks is negatively related to age). This difference could simply be due to the relatively young age, as well as the limited range of ages, of the sample (the respondents were born between 1964 and 1971 and were interviewed between 2004 and 2007).

Columns (ii) to (v) of Table 2 contain the estimates of the model of heritability. Here the sample is treated as one of twins. Preliminary estimation showed that the estimate of $c^{2}$ was not significant. This has been constrained to zero in Table 2 (see also Cesarini et al., 2009;Zyphur et al., 2009). The estimate of heritability $\left(h^{2}\right)$ in the column (ii) model is $0.221 .^{9}$ This is very similar to the estimate reported by Cesarini et al. (2009) and in Le et al. (2010). This shows that analysis using the select sample of workers in paid employment does not alter the assessment of the importance of heritability. Comparison of the other estimates with those in Le et al. (2010) indicates that similar comments apply. Hence, no adjustment for the truncation of the sample (to individuals in paid employment) is considered.

The results in column (iii), following the addition of the variables for female, educational attainment and age to the model of DeFries and Fulker (1985), show that these have a modest impact on the estimate of heritability. Likewise, the statistical control for genetic factors has relatively little impact on the estimated partial effects of the female, educational attainment and age variables (compare columns (i) and (iii)).

The findings in columns (iv) and (v), which address the hypothesis that heritability differs between males and females, show a clear lack of evidence in support of this hypothesis. In all the equations estimated, the female variable is associated with a large, significant and negative coefficient.

Thus, females are more risk averse than males, and this would be expected to impact their relative labor market outcomes. The importance of attitudes towards risk in the determination of earnings is considered below.

\footnotetext{
${ }^{7}$ The mean for males is 4.893 (standard deviation of 1.993) and that for females 4.132 (2.036).

${ }^{8}$ Note, however, that the direction of causation in relation to the education variable is likely to be ambiguous.

${ }^{9}$ Estimation of a biometric variance components (A + E) model using maximum likelihood gives a value of A of 0.219. See McArdle and Prescott (2005) for the procedure.
} 


\section{(b) Earnings}

The models of earnings adopted in this study are the conventional human capital earnings equation and this human capital earnings equation augmented with the variables described in Section II that enable the genetic and common environmental influences to be captured. In general form these models may be represented as:

$\mathrm{EARN}=\mathrm{f}$ (genetic factors, common environmental factors, educational attainment, female, age, part-time)

The age information is included in the estimating equation in Gompertz form (specifically, Gage $=\exp \left(-0.1^{*}\right.$ Age $\left.)\right)$, as this is the specification of the age variable adopted in previous analyses of samples of young-to-middle-age twins (e.g., Le et al., 2005). The justification provided for this approach is that the Gompertz functional form captures the non-linearity in the earnings-age profiles without the negative partial effects that are associated with ages beyond around 40 years when a quadratic specification is used. In addition, a variable for the type of employment (full-time or part-time) is entered into the estimating equation: the only labor supply information in the data set is for whether the person works full-time or parttime. Previous analyses of the Australian Twins Registry data have shown that the part-time employment variable is an important determinant of earnings (see Miller, Mulvey and Martin, 2006).

Table 3 contains the estimates of the conventional model for earnings determination. Separate equations are estimated for males and females.

Columns (i) and (iii) contain estimates of the human capital earnings equation without the economic risk variable. These show that the payoff to education is around 8 percent for males and 7 percent for females, although these two estimates are not significantly different. These figures are comparable with findings in Miller et al. (1995) (2006). Earnings increase with age, with the partial effect being around 2.0 percent for males at 35 years of age (2.3 percent for females), and 1.2 percent at 40 years of age (1.4 percent for females). Again, however, these estimates for males and females do not differ significantly. The coefficient on the part-time employment variable is -0.785 for females and -0.889 for males, and these effects are on par with that reported by Miller, Mulvey and Martin (2006), where the estimated effects in the OLS models ranged from -0.767 to -0.807 .

Columns (ii) and (iv) are distinguished by the addition of the attitudes towards economic risk variable. These results show that the inclusion of the risk variable in the estimating equation has a small impact on the other estimated coefficients. Each one-point rise in the measure of attitudes towards economic risk is associated with a 3.4 percent increase in earnings for males, and a 2.4 percent increase in earnings for females. This difference of one percentage point, however, is not statistically significant ( ' $t$ ' $=0.88$ ). Thus, there would be a difference of around 31 percent between the least risk averse and the most risk averse male in the data. ${ }^{10}$ For females this difference would be 22 percent. These effects associated with the risk variable are the equivalent of the difference in earnings associated with around four years of education. ${ }^{11}$

Finally, the estimate of the gender wage differential is slightly more than 20 percent, and this is consistent with previous Australian studies, particularly those that have limited

\footnotetext{
$10_{0.306}=$ risk earnings effect $*$ (top risk rating - bottom risk rating $)=0.034 *(10-1)$.

${ }^{11}$ This effect is almost twice as strong as the impact of risk attitude on earnings in Bonin et al.'s (2007) study of the earnings of men in Germany, although the measure of risk in that paper was more general than that used in the current study, as it was based on responses to the question: "How do you see yourself: Are you generally a person who is completely willing to take risks or do you try to avoid taking risks?"
} 
statistical controls and limited labor supply information (see, for example, the summary of findings presented in Table 1 of Borland (1999)). The inclusion of the economic risk variable in the model of column (v) is associated with a reduction of the standardized female wage disadvantage of 2.3 percentage points (coefficient on the female variable changes from -0.262 with a ' $t$ ' of 10.03 to -0.239 with a ' $t$ ' of 9.04).

We also examined whether the earnings risk premium varied by occupation of employment. The two highest paid occupational categories, of professionals and managers, were distinguished from other occupations, and a dummy variable for employment in these occupations included in the earnings equation, along with an interaction term between this occupation variable and the attitudes towards economic risk variable. While the point estimate of the coefficient on the interaction term was positive, the estimated effect was small and statistically insignificant. ${ }^{12}$

The estimate of the earnings-risk relationship in Table 3 could be biased owing to omitted variables, including ability and family background. Before proceeding to use the estimates, therefore, it is worthwhile examining the impact of the control for these factors that can be effected through estimation of the behavioral genetics model outlined in Section II. Selected results are presented in Table 4 . The point estimate of $c^{2}$ was negative in the preliminary estimations, and this component of the behavioral genetics model has been constrained to equal zero in the preferred specification. The column (i) results in Table 3 show that earnings are broadly heritable in Australia, with the point estimate of $h^{2}$ being $0.46 .{ }^{13}$ Taubman's (1976) earlier study for the US had $h^{2}$ of between 18 and 41 percent. Hence, the Table 4 estimates are consistent with the literature, in assigning a large component of the variation in earnings to genetic influences.

Column (ii) includes the variables for educational attainment, female, age and risk. The inclusion of these variables is associated with a sharp drop in the estimate of $h^{2}$, from 0.46 to 0.20 . This is due to the inclusion of the educational attainment variable, which itself has a large heritable component ( $h^{2}$ is typically 0.4 or more in Australian data). The payoff to years of educational attainment is 6.2 percent, and this figure is comparable with findings in Table 3. This small change between the Table 3 and Table 4 estimates is consistent with the modest role ascribed to ability in earnings determination in the Ashenfelter and Krueger (1994) research, and the papers that followed this particular study. ${ }^{14}$ The estimate of the gender wage differential is close to 20 percent, and this is consistent with the evidence presented in Table 3. Importantly, the estimated risk coefficient is 0.025 , which is broadly the same as the estimate of 0.029 in column (v) of Table 3.

The approximately 0.8 point difference between men and women in the measure of attitudes towards economic risk could account for, at best, slightly less than a three percentage point difference in earnings. This is found by applying the estimated coefficient for males to the gender difference in the measure of attitudes towards economic risk (i.e., $0.034(4.893-4.132)=0.026)$. Thus, to account for the standardized gender pay effect in these data, the impact of attitudes towards economic risk on earnings would need to be around eight times that estimated in Table 3 . Hence, while attitudes towards economic risk are positively and significantly related to earnings, the partial effect is such that even the quite considerable difference between males and females in the attitudes towards economic risk accounts for only a minor part of the gender pay gap.

\footnotetext{
${ }^{12}$ Another approach to the examination of these data would be to relate attitudes towards economic risk to gender differences in occupational choice. This is a topic of on-going research.

${ }^{13}$ The maximum likelihood estimate of this in an A+E model was 0.465 .

${ }^{14}$ Earlier research by Behrman, Hrubec, Taubman and Wales (1980), however, reported a more important role for ability in earnings determination.
} 


\section{SUMMARY AND CONCLUSION}

This study has examined the extent to which gender differences in attitudes towards economic risk can account for the gender pay gap. Attitudes towards economic risk are viewed as an influence on individual decision-making processes that affect labor market outcomes and hence may account for part of the variation in earnings. The analyses show that these are moderately heritable. There is no evidence that this heritability differs between males and females. The considerable difference between males and females in the measure of attitudes towards economic risk persists when multivariate models are estimated that take account of differences in educational attainment, age and genetic and common environment (i.e. family up-bringing) factors. The differences in the measure of risk is 0.761 percentage points in the unadjusted data, and between 0.741 and 0.819 in the statistically adjusted data.

Workers with more positive attitudes towards economic risk earn higher earnings than more risk averse workers. Each one point on the risk attitude scale (from one to ten) is associated with 3.4 percent higher earnings among males, and 2.4 percent higher earnings among females. This difference between these earnings effects is not statistically significant.

Applying the male wage premium associated with favorable attitudes towards economic risk to the gender difference in the mean of the measures shows that the gender difference in attitudes towards economic risk could account for just three percentage points of the approximately 24 percentage points gender pay gap. Hence, while gender differences in attitudes towards economic risk, or gender differences in decision making that the attitudes towards risk reflect, are substantial, they can account for only a small part of the standardized gender wage gap reported in the literature. To account for all of the residual gender wage effect, the earnings effects would need to be almost eight-times greater than those estimated. Hence, while gender differences in attitudes towards economic risk are important to the understanding of the gender pay gap, they account for only a small part of this inequality.

\section{APPENDIX A: DESCRIPTION OF THE DATA}

The variables used in the analysis are standard, and descriptions are provided only for the non-standard variables.

\section{Age}

Age is entered into the earnings equations in Gompertz form. The specific functional form is Gage $=e^{-0.1 \times \text { Age }}$.

\section{Risk}

Attitudes towards economic risk are assessed using responses to the question: "On a scale from 1 to 10 , with 1 meaning no risk, and 10 meaning extremely high risk, how much risk are you willing to tolerate when deciding how to invest your money?"

\section{Education}

The data on education are collected in categorical form: (a) 8-10 years of schooling; (b) matriculation/year 12; (c) technical, teachers college, Technical and Further Education institute, business or secretarial college; (d) university undergraduate training; (e) university post-graduate training. Full-time years equivalents have been assigned to these categories to form a continuous education variable. 


\section{Earnings}

The earnings data were collected in categorical form: (a) $\$ 1,000-\$ 9,999$; (b) $\$ 10,000$ -

$\$ 19,999$; (c) $\$ 20,000-\$ 24,999$; (d) $\$ 25,000-\$ 29,999$; (e) $\$ 30,000-\$ 34-999$; (f) $\$ 35,000$ -

$\$ 39,999$; (g) $\$ 40,000-\$ 49,999$; (h) $\$ 50,000-\$ 74,999$, (i) $\$ 75,000-\$ 99,999$; (i) $\$ 100,000$ -

$\$ 149,999$; (k) $\$ 150,000$ or more. Mid-points are used for the closed intervals, and a value of $\$ 225,000$ for the open-ended upper interval.

\section{Appendix Table 1}

Means of Variables by Gender, Purged Sample with Positive Earnings

\begin{tabular}{|lccc|}
\hline Variable & Males & Females & Pooled Sample \\
\hline Female & 0.0 & 1.0 & 0.467 \\
Age & 37.528 & 37.904 & 37.703 \\
Education & 13.401 & 13.751 & 13.564 \\
Economic Risk & 4.893 & 4,132 & 4.538 \\
Earnings (\$) & 74,219 & 43,384 & 59,826 \\
Part-time & 0.027 & 0.047 & 0.232 \\
Sample Size & 1220 & 1068 & 2288 \\
\hline
\end{tabular}

\section{Appendix Table 2}

Means of Variables by Gender, Full Sample

\begin{tabular}{|lccc|}
\hline Variable & Males & Females & Pooled Sample \\
\hline Female & 0.0 & 1.0 & 0.573 \\
Age & 37.622 & 37.708 & 37.671 \\
Education & 13.224 & 13.341 & 13.291 \\
Economic Risk & 4.770 & 4.113 & 4.394 \\
Sample Size & 2023 & 2712 & 4735 \\
\hline
\end{tabular}

\section{REFERENCES}

Ashenfelter O, Krueger A. Estimates of the Economic Return to Schooling from a New Sample of Twins. American Economic Review. 1994; Vol. 84(No. 5):1157-1173.

Baker LA, Treloar SA, Reynolds CA, Heath AC, Martin NG. Genetics of Educational Attainment in Australian Twins: Sex Differences and Secular Changes. Behavior Genetics. 1996; Vol. 26(No. 2): 89-102. [PubMed: 8639155]

Behrman, J.; Hrubec, Z.; Taubman, P.; Wales, TJ. Socioeconomic Success: A Study of the Effects of Genetic Endowments, Family Environment, and Schooling. North Holland Publishing Company; New York: 1980.

Blau FD, Kahn LW. Swimming Upstream: Trends in the Gender Wage Differential in the 1980s. Journal of Labor Economics. 1997; Vol. 15(No. 1, Part 1):1-42.

Blinder AS. Wage Discrimination: Reduced Form and Structural Estimates. Journal of Human Resources. 1973; Vol. 8(No. 4):436-455.

Bonin H, Dohmen T, Falk A, Huffman D, Sunde U. Cross-sectional Earnings Risk and Occupational Sorting: The Role of Risk Attitudes. Labour Economics. 2007; Vol. 14:926-937.

Borland J. The Equal Pay Case-Thirty Years On. The Australian Economic Review. 1999; Vol. 32(No. 3):265-272. 
Cesarini D, Dawes CT, Johannesson M, Lichtenstein P, Wallace B. Genetic Variation in Preferences for Giving and Risk Taking. The Quarterly Journal of Economics. 2009; Vol. 124(No. 2):809-842.

Cherny SS, DeFries JC, Fulker DW. Multiple Regression Analysis of Twins Data: A Model-Fitting Approach. Behavior Genetics. 1992; Vol. 22(No. 4):489-497. [PubMed: 1503550]

DeFries JC, Fulker DW. Multiple Regression Analysis of Twins Data. Behavior Genetics. 1985; Vol. 15(No. 5):467-473. [PubMed: 4074272]

DeFries, JC.; Gillis, JJ.; Wadsworth, SJ. Genes and Gender: A Twin Study of Reading Disability. In: Galaburda, Albert M., editor. Dyslexia and Development: Neurobiological Aspects of ExtraOrdinary Brains. Harvard University Press, Cambridge; Massachusetts, USA: 1993. p. 187-204.

Dohmen, T.; Falk, A.; Huffman, D.; Sunde, U.; Schupp, J.; Wagner, GG. IZA Discussion Paper No. 1730. Bonn; Germany: 2005. Individual Risk Attitudes: New Evidence from a Large, Representative, Experimentally-Validated Survey.

Eckel CC, Grossman PJ. Sex Differences and Statistical Stereotyping in Attitudes Towards Financial Risk. Evolution and Human Behavior. 2002; Vol. 23(No. 4):281-295.

Heckman JJ. Sample Selection Bias as a Specification Error. Econometrica. 1979; Vol. 47(No.1):153161.

Le AT, Miller PW, Heath A, Martin NG. Early Childhood Behaviours, Schooling and Labour Market Outcomes: Estimates from a Sample of Twins. Economics of Education Review. 2005; Vol. 24(No. 1):1-17.

Le AT, Miller PW, Slutske WS, Martin NG. Are Attitudes Towards Economic Risk Heritable? Analyses Using the Australian Twin Study of Gambling. Twin Research and Human Genetics. 2010; Vol. 13(No. 4):330-339. [PubMed: 20707703]

McArdle JJ, Prescott CA. Mixed-Effects Variance Components Models for Biometric Family Analyses. Behavior Genetics. 2005; Vol. 35(No. 5):631-652. [PubMed: 16184490]

Martin, NG. Genetics of Sexual and Social Attitudes in Twins. In: Nance, WE., editor. Twin Research: Psychology and Methodology. Alan R. Liss; New York: 1978. p. 13-23.

Martin NG, Wilson SR. Bias in the Estimation of Heritability from Truncated Samples of Twins. Behavior Genetics. 1982; Vol. 12(No. 4):467-472. [PubMed: 6890347]

Miller PW. The Wage Effect of the Occupational Segregation of Women in Britain. The Economic Journal. 1987a; Vol. 97(No. 388):885-896.

Miller PW. Gender Differences in Observed and Offered Wages in Canada, 1980. Canadian Journal of Economics. 1987b; Vol. 20:225-244.

Miller PW, Mulvey C, Martin NG. What Do Twins Studies Reveal About the Economic Returns to Education?: A Comparison of Australian and U.S. Findings. American Economic Review. 1995; Vol. 85(No. 3):586-599.

Miller PW, Mulvey C, Martin NG. Genetic and Environmental Contributions to Educational Attainment in Australia. Economics of Education Review. 2001; Vol. 20(No. 3):211-224.

Miller PW, Mulvey C, Martin NG. The Return to Schooling: Estimates from a Sample of Young Australian Twins. Labour Economics. 2006; Vol. 13(No. 5):571-587.

Oaxaca R. Male-Female Wage Differentials in Urban Labor Markets. International Economic Review. 1973; Vol. 14(No. 3):693-709.

Polachek SW. Differences in Expected Post-School Investment as a Determinant of Market Wage Differentials. International Economic Review. 1975; Vol. 16(No. 2):451-470.

Powell M, Ansic D. Gender Differences in Risk Behaviour in Financial Decision-Making: An Experimental Analysis. Journal of Economic Psychology. 1997; Vol. 18(No. 6):605-628.

Puhani PA. The Heckman Correction for Sample Selection and its Critique. Journal of Economic Surveys. 2000; Vol. 14(No. 1):53-68.

Schubert R, Brown M, Gysler M, Brachinger HW. Financial Decision-Making: Are Women Really More Risk Averse. American Economic Review, Papers and Proceedings. 1999; Vol. 89(No. 2): 381-385.

Slutske WS, Meier MH, Zhu G, Statham DI, Blaszczynski A, Martin NG. The Australian Twin Study of Gambling (OZ-GAM): Rationale, Sample Description, Predictors of Participation, and a First 
Look at Sources of Individual Differences in Gambling Involvement. Twin Research and Human Genetics. 2009; Vol. 12(No. 1):63-78. [PubMed: 19210181]

Taubman P. The Determinants of Earnings: Genetics, Family, and Other Environments; A Study of White Male Twins. American Economic Review. 1976; Vol. 66(No. 5):858-870.

Zyphur MJ, Narayanan J, Arvey RD, Alexander GJ. The Genetics of Economic Risk Preferences. Journal of Behavioral Decision Making. 2009; Vol 22(No. 4):367-377. 


\section{Table 1}

Distribution and Mean of Responses to Question "On a scale of 1 to 10, with 1 meaning no risk, and 10 meaning extremely high risk, how much risk are you willing to tolerate when deciding how to invest your money?" by Gender

\begin{tabular}{|cccc|}
\hline & & \multicolumn{2}{c|}{ Gender } \\
\cline { 3 - 4 } RISK & $\begin{array}{c}\text { Total } \\
\text { (i) }\end{array}$ & $\begin{array}{c}\text { Males } \\
\text { (iv) }\end{array}$ & $\begin{array}{c}\text { Females } \\
\text { (v) }\end{array}$ \\
\hline 1 & 9.88 & 6.72 & 13.48 \\
2 & 6.95 & 5.41 & 8.71 \\
3 & 16.39 & 14.02 & 19.10 \\
4 & 11.54 & 10.90 & 12.27 \\
5 & 24.56 & 26.07 & 22.85 \\
6 & 12.46 & 13.93 & 10.77 \\
7 & 12.19 & 15.57 & 8.33 \\
8 & 4.15 & 5.16 & 3.00 \\
9 & 0.26 & 0.33 & 0.19 \\
10 & 1.62 & 1.89 & 1.31 \\
Total & $\mathbf{1 0 0 . 0 0}$ & $\mathbf{1 0 0 . 0 0}$ & $\mathbf{1 0 0 . 0 0}$ \\
Sample Size & 2288 & 1220 & 1068 \\
\hline Mean Score & 4.538 & 4.893 & 4.132 \\
\hline
\end{tabular}

Source: Authors' calculations from the Australian Twin Study of Gambling. 
Table 4

Estimates of Multiple Regression Model of Heritability of Earnings

\begin{tabular}{|lcc|}
\hline Variable & (i) & (ii) \\
\hline Constant & 6.164 & 5.647 \\
& $(96.98)$ & $(50.15)$ \\
EARN $_{-i j}$ & 0.0 & 0.0 \\
$\mathrm{R}_{\mathrm{j}}$ & -2.822 & -1.317 \\
& $(11.82)$ & $(6.26)$ \\
$\mathrm{R}_{\mathrm{j}} \times$ EARN $_{\mathrm{ij}}$ & 0.456 & 0.205 \\
& $(12.55)$ & $(6.15)$ \\
Female $_{\mathrm{ij}}$ & (a) & -0.188 \\
& & $(5.02)$ \\
Female $_{\mathrm{ij}} \times \mathrm{R}_{\mathrm{j}}$ & (a) & $(\mathrm{a})$ \\
Female $_{\mathrm{ij}} \times \mathrm{R}_{\mathrm{j}} \times$ & (a) & $(\mathrm{a})$ \\
EARN $_{-\mathrm{ij}}$ & & \\
Age $_{\mathrm{ij}}$ & (a) & -5.914 \\
& & $(2.07)$ \\
Education $_{\mathrm{ij}}$ & (a) & 0.062 \\
& & $(10.76)$ \\
Part-Time $_{\text {Employment }_{\mathrm{ij}}}$ & (a) & -0.762 \\
Economic Risk $_{\mathrm{ij}}$ & (a) & $(17.12)$ \\
& & 0.025 \\
\hline Adjusted R $^{2}$ & 0.128 & 0.449 \\
True Sample Size & 1,144 & 1,144 \\
\hline
\end{tabular}

Notes: Robust ' $t$ ' statistics in parentheses, adjusted to degrees of freedom of the true sample size; estimations constrain $\mathrm{c}^{2}=0$; $(\mathrm{a})=$ variable not entered. 